\title{
Identification of Adrenal Insufficiency Leading to a Diagnosis of POEMS Syndrome
}

\author{
Tomoya Tsuchida ${ }^{1}$, Hisashi Nishisako ${ }^{1}$, Masahiro Hirose ${ }^{1}$, \\ Kana Igarashi $^{2}$, Chiaki Okuse ${ }^{1}$, and Takahide Matsuda ${ }^{1}$
}

(Received for Publication: February 22, 2018)

\begin{abstract}
A 57-year-old Japanese man with abdominal distention was referred to gastroenterologists at our hospital, where abdominal computed tomography revealed ascites and swollen lymph nodes. He was admitted for testing and treatment. Suffering from unremitting hyponatremia, hyperkalemia, hypotension, and hypoglycemia, he was transferred to our division for electrolyte correction and further diagnosis. Hormone stimulation testing revealed adrenal insufficiency. Upon electrophysiology, immunoelectrophoresis, and measurement of vascular endothelial growth factor, POEMS syndrome was diagnosed. POEMS syndrome may underlie adrenal insufficiency and should be considered when polyneuropathy, ascites, and swollen lymph nodes occur along with adrenal insufficiency.
\end{abstract}

\section{Key words}

Electrolyte abnormalities, Adrenal insufficiency, POEMS syndrome

\section{Introduction}

POEMS (acronym for polyneuropathy, organomegaly, endocrinopathy, monoclonal gammopathy, and skin changes) syndrome is a multisystemic disease characterized by such symptoms as numbness, tingling, and weakness of the legs; edema, pleural effusion, ascites, and an enlarged spleen; adrenal insufficiency; and hyperpigmentation and angiomas. Although endocrine abnormalities are noted in about $80 \%$ of patients with POEMS syndrome ${ }^{1)}$, there are not many reports of adrenal insufficiency in patients with the syndrome. Moreover, in none of the reported cases has POEMS syndrome been diagnosed upon detection of adrenal insufficiency. We encountered a patient who was diagnosed with adrenal insufficiency, and this led to a diagnosis of POEMS syndrome.
Case

The patient was a 57-year-old Japanese man who, for 2 months, had suffered numbness in both lower limbs. He had also noticed darkened skin, predominantly on his legs. He had visited his local physician, complaining of abdominal bloating, and a few weeks later, he was referred to the Department of Gastrointestinal Surgery at our hospital for further examination and treatment. It was noted that he was taking aspirin and losartan because of a previous cerebral infarction, but his family history was unremarkable. Abdominal plain computed tomography (CT) was performed, and edematous change and fluid accumulation in the intestines, ascites, and swollen lymph nodes throughout the peritoneal cavity were revealed, so the patient was admitted. There was no obvious sign of gastrointestinal obstruction. He was treated by fasting, intravenous extracellular fluid transfusion, and paracentesis. The abdominal disten-

1 Kawasaki Municipal Tama Hospital, Division of General Internal Medicine, St. Marianna University School of Medicine

2 Division of Metabolism and Endocrinology, St. Marianna University School of Medicine 
tion did not worsen, and the fasting was discontinued on hospital day 3. Peritoneal fluid was examined cytologically, and there was no evidence of malignancy. The patient had no difficulty eating and was able to ingest full meals, but on admission, blood chemistry tests had shown a sodium (Na) concentration of 139 $\mathrm{mEq} / \mathrm{L}$ and potassium $(\mathrm{K})$ concentration of 5.6 $\mathrm{mEq} / \mathrm{L}$. On hospital day 3, the Na concentration was $134 \mathrm{mEq} / \mathrm{L}$, and the $\mathrm{K}$ concentration was $4.7 \mathrm{mEq} / \mathrm{L}$. By hospital day 12 , the $\mathrm{Na}$ concentration had decreased markedly to $121 \mathrm{mEq} / \mathrm{L}$, and the $\mathrm{K}$ concentration had increased markedly to $7.7 \mathrm{mEq} / \mathrm{L}$. At this point, the patient was referred to our Division of General Internal Medicine for urgent correction of the electrolyte levels and for a determination of the cause of the fluctuations. At the time of admission to our division, the patient was alert, his blood pressure was $95 / 57 \mathrm{mmHg}$, his pulse was regular at 56 beats/ min, and his thyroid was not enlarged. No cervical or axillary lymph nodes were palpable, but approximately $3 \mathrm{~cm}$ was palpated in his right groin. His abdomen was distended and soft but not tender. Hyperpigmentation on his lower limbs was noted, and the hair on his legs was bristly. Pitting edema of both lower limbs was noted. The patient reported that the numbness he had noticed in both legs before admission had worsened progressively. A manual muscle test was performed, revealing that muscle strength of the upper and lower limbs was only somewhat decreased (score 4/5) on both sides. There were no pathologic reflexes. The lower limbs were more sensitive to touch and pain than were the upper limbs. There was no autonomic impairment and no obvious cerebellar abnormality. Results of cognitive and neurological function tests were normal. Blood chemistry tests revealed a blood urea nitrogen $(\mathrm{BUN})$ concentration of $41.8 \mathrm{mg} / \mathrm{dL}$, creatinine (Cre) concentration of $1.33 \mathrm{mg} / \mathrm{dL}, \mathrm{Na}$ concentration of $121 \mathrm{mEq} / \mathrm{L}, \mathrm{K}$ concentration of $7.7 \mathrm{mEq} / \mathrm{L}$, chloride (Cl) concentration of $95 \mathrm{mEq} / \mathrm{L}$, and glucose $(\mathrm{Glu})$ concentration of $70 \mathrm{mg} / \mathrm{dL}$. In other words, the BUN and Cre concentrations were elevated, and hyponatremia, hyperkalemia were present (Table 1). The blood cell counts and hepatobiliary enzyme concentrations were normal; the total protein concentration was 7.1 $\mathrm{g} / \mathrm{dL}$, and the albumin concentration was normal at $4.1 \mathrm{~g} / \mathrm{dL}$. The HbA1c level was $5.0 \%$. On hospital day 5 (before the patient had been admitted to our division), contrast-enhanced $\mathrm{CT}$ from the chest to the lower abdomen revealed an increase in the peritoneal fluid volume; hepatosplenomegaly; and swollen in-
Table 1. Blood Test Results Before The Patient was Transferred to Our Division.

\begin{tabular}{lccccc}
\hline & \multicolumn{5}{c}{ Hospital day } \\
\cline { 2 - 6 } & 1 & 3 & 6 & 8 & 12 \\
\hline $\mathrm{Na}(\mathrm{mEq} / \mathrm{L})$ & 139 & 134 & 131 & 122 & 121 \\
$\mathrm{Cl}(\mathrm{mEq} / \mathrm{L})$ & 105 & 100 & 99 & 93 & 95 \\
$\mathrm{~K}(\mathrm{mEq} / \mathrm{L})$ & 5.6 & 4.7 & 5.3 & 6.6 & 7.7 \\
$\mathrm{Na} / \mathrm{K}$ & 24.8 & 28.5 & 24.7 & 18.5 & 15.7 \\
$\mathrm{BUN}(\mathrm{mg} / \mathrm{dL})$ & 25.4 & 17.7 & 13.0 & 27.4 & 41.6 \\
$\mathrm{Cre}(\mathrm{mg} / \mathrm{dL})$ & 1.31 & 1.14 & 1.17 & 1.07 & 1.33 \\
$\mathrm{WBC}(\mu / \mathrm{L})$ & 8100 & 6900 & 4600 & 5300 & 5000 \\
Eosinophils $(\%)$ & 1 & 1.3 & - & - & 1.5 \\
Glu $(\mathrm{mg} / \mathrm{dL})$ & - & - & 85 & - & 70 \\
\hline
\end{tabular}

$\mathrm{Na}$ sodium, $\mathrm{Cl}$ : chloride, $\mathrm{K}$ : potassium, BUN: blood urea nitrogen, Cre: creatinine, WBC: white blood cell count, Glu: glucose, - not tested

guinal, periaortic, and mediastinal lymph nodes. The adrenal glands appeared morphologically normal (Fig. 1 A-C). Calcium gluconate was administered to treat the hyperkalemia, and glucose-insulin therapy was started. The losartan was discontinued, and by hospital day 19 , the patient's $\mathrm{K}$ concentration decreased to $4.0 \mathrm{mEq} / \mathrm{L}$. The course of the illness suggested adrenal insufficiency, and hormone stimulation tests were performed. In the blood collected at rest in the morning, the cortisol concentration was $12.8 \mu \mathrm{g} / \mathrm{dL}$ (a concentration below $4 \mu \mathrm{g} / \mathrm{dL}$ suggests adrenal insufficiency, and, whereas a concentration of $18 \mu \mathrm{g} / \mathrm{dL}$ or above precludes adrenal insufficiency, a concentration of 4 to $18 \mu \mathrm{g} / \mathrm{dL}$ does not preclude the disorder), and the adrenocorticotropic hormone (ACTH) concentration was $84 \mathrm{pg} / \mathrm{mL} \quad(7.2-63.3$ $\mathrm{pg} / \mathrm{mL})$. An adrenocorticotropic hormone $(250 \mu \mathrm{g})$ stimulation test revealed a cortisol concentration of $14.5 \mu \mathrm{g} / \mathrm{dL}$ (i.e., no increase) (Fig. 2), and a corticotropin-releasing hormone $(\mathrm{CRH})$ stimulation test revealed a cortisol level of $12.9 \mu \mathrm{g} / \mathrm{dL}$ (no change, although the ACTH concentration had increased to 170 ng/mL) (Fig. 3). Thus, primary adrenal insufficiency was diagnosed. Thyroid function tests revealed a free triiodothyronine (FT3) concentration of $0.92 \mathrm{ng} / \mathrm{dL}$, a free thyroxine (FT4) concentration of $2.09 \mathrm{ng} / \mathrm{dL}$, and a thyroid-stimulating hormone (TSH) concentration of $11.412 \mu \mathrm{IU} / \mathrm{mL}$, subclinical hypothyroidism . The anti-thyroid peroxidase and anti-thyroglobulin antibody titers were not elevated $(<5$ and $<10$, respectively), ruling out Hashimoto's disease. Assessment of gonad function, parathyroid function, and pituitary function revealed a testosterone concentration of 5.58 $\mathrm{ng} / \mathrm{mL}$ (2.0-7.6), an intact parathyroid hormone concentration of $54 \mathrm{pg} / \mathrm{mL}(10-60)$, a prolactin (PRL) concentration of $16.15 \mathrm{ng} / \mathrm{mL}$ (3.6-12.8), growth 

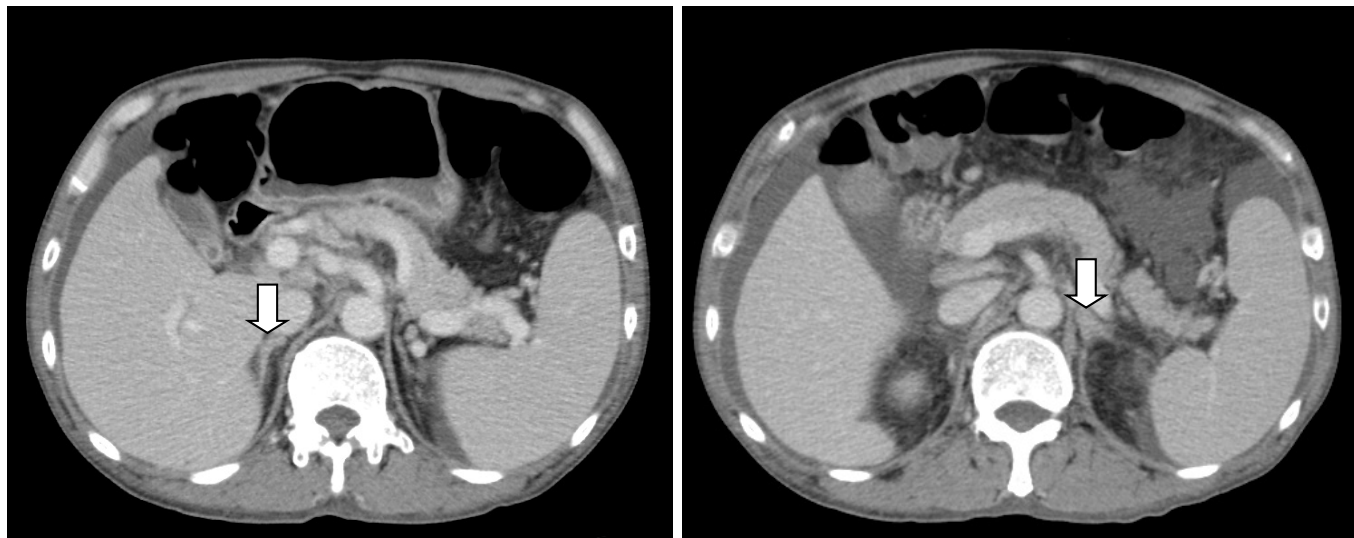

A) Hepatosplenomegaly and ascites are evident. Neither adrenal enlargement nor atrophy is evident on the right or left. Left and right adrenal glands (Љ).

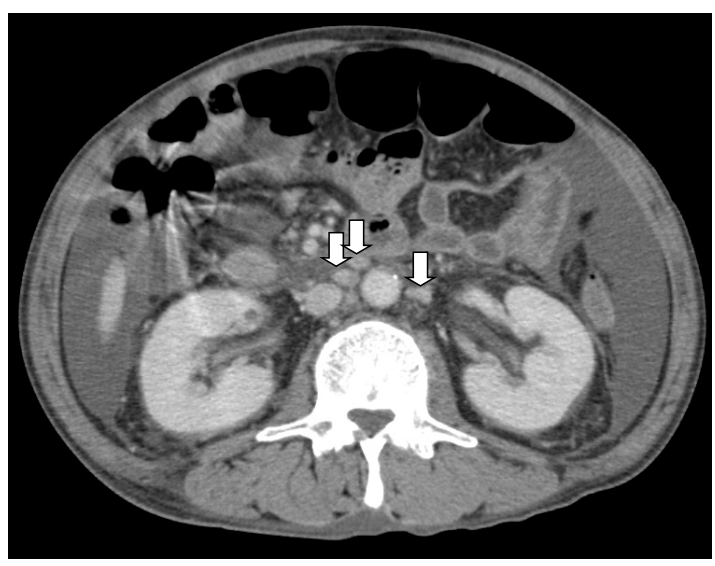

B) Swollen periaortic lymph nodes are evident (Љ).

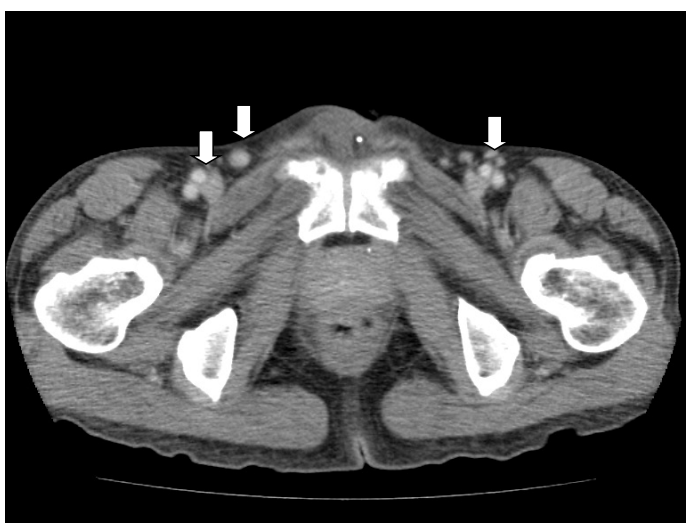

C) Swollen inguinal lymph nodes are evident (Љ).

Figure 1. Abdominal contrast-enhanced computed tomography images obtained on hospital day 5.

\section{Cortisol $(\mu \mathrm{g} / \mathrm{dL})$}

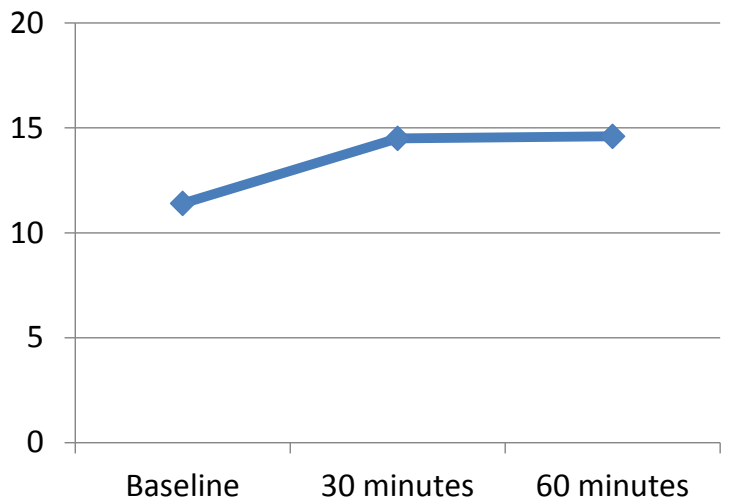

Figure 2. Results of rapid adrenocorticotropic hormone $(250 \mu \mathrm{g})$ stimulation test performed. (Hospital day24)

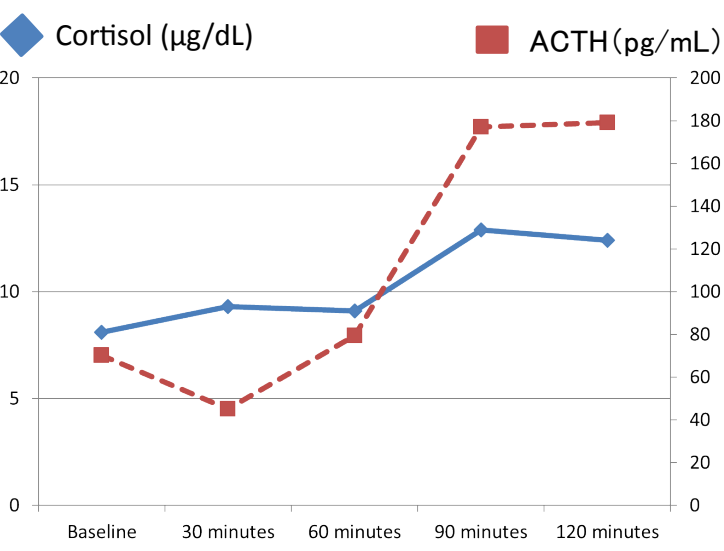

Figure 3. Results of corticotropin-releasing hormone loading test performed (Hospital day28). 
hormone $(\mathrm{GH})$ concentration of $1.98 \mathrm{ng} / \mathrm{mL}(\leq 0.42$ $\mathrm{ng} / \mathrm{mL}$ is normal), luteinizing hormone (LH) concentration of $5.93 \mathrm{mIU} / \mathrm{mL}(1.7-8.6)$, and follicle-stimulating hormone (FSH) concentration of $8.00 \mathrm{mIU} / \mathrm{mL}$ (1.5-12.4). Quadruple injection test of hypothalamic peptide revealed no abnormalities except a poor cortisol response. Hydrocortisone (7.5 mg in the morning, $2.5 \mathrm{mg}$ in the evening) was administered for treatment of the adrenal insufficiency; the electrolyte abnormalities and hypoglycemia disappeared. Motor nerve and sensory nerve conduction velocities were measured, and both were found to be decreased; latency was also prolonged, and thus polyneuropathy was diagnosed. The increased pigmentation and bristling of the hair spread across the patient's entire body. Inguinal lymph node biopsy was performed, but there was no indication of malignancy. Lymphoid follicles mixed with atrophic germinal centers and lymphoid follicles with enlarged germinal centers were noted. Hyperplasia with high endothelial venules was noted (Fig. 4). Malignancy was judged to be unlikely, given the endocrine abnormalities, polyneuropathy, skin changes, and results of peritoneal fluid cytology and lymph node biopsy. POEMS syndrome was considered in the differential diagnosis. Additional testing revealed the presence of monoclonal $\operatorname{IgA}(\lambda)$ protein in the patient's urine, and the serum vascular endothelial growth factor (VEGF) con-

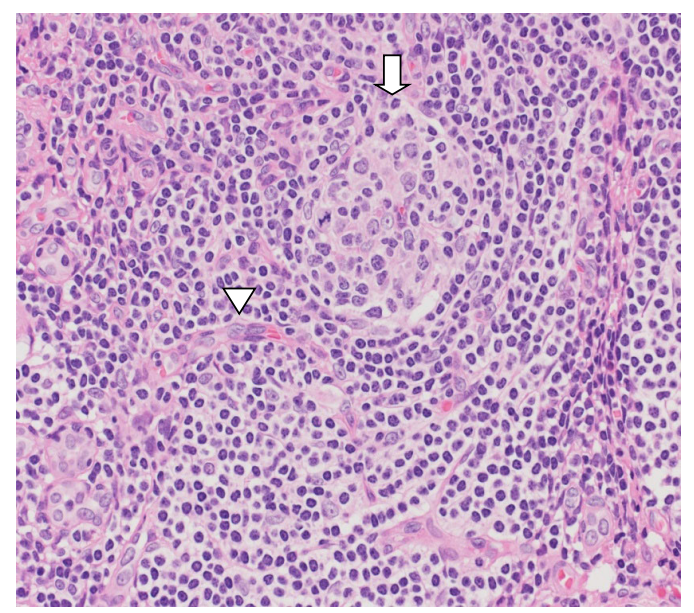

Figure 4. High-magnification image of a hematoxylin and eosin-stained section of the inguinal lymph node specimen. Noted are a high endothelial venule (proliferation of endothelial cells of the venule) $(\nabla)$ and lymphoid follicle with an atrophic germinal center (Љ). centration was 6,130 pg/mL (normal: $229 \pm 147$ $\mathrm{pg} / \mathrm{mL}$ ). At this point, POEMS syndrome was diagnosed definitively, and the patient was transferred to another hospital for specialized treatment. The patient now takes thalidomide regularly and continues to receive dexamethasone pulse therapy. He has been discharged, but he is followed up regularly in a specialized outpatient services clinic at our hospital and at another hospital.

\section{Discussion}

POEMS syndrome is a multisystemic disease characterized by monoclonal proliferation of plasma cells and such manifestations as polyneuropathy, edema, pleural effusion or ascites, organomegaly, endocrinopathy, skin changes (hyperpigmentation and/or angiomas), and monoclonal gammopathy ${ }^{2}$. On the basis of a nationwide survey conducted in 2003, the Research Committee on Autoimmune Neurological Disorders of the Ministry of Health, Labour, and Welfare of Japan estimated the number of patients at about $340^{3)}$. Awareness of POEMS syndrome is limited, however, so it is possible that many cases have gone undiagnosed. Because POEMS syndrome has various clinical manifestations, the departments to which patients initially present vary. General internists and the various subspecialists must be aware of this condition so that it can be diagnosed and treated early ${ }^{4}$. An essential diagnostic criterion for POEMS syndrome is polyneuropathy. Two other major criteria are serum VEGF elevation ( $1000 \mathrm{pg} / \mathrm{mL}$ or higher) and the presence of monoclonal proteins, and minor criteria are osteosclerotic lesions, Castleman's disease, organomegaly, edema, pleural effusion, ascites, pericardial effusion, endocrine abnormalities, skin abnormalities, papilledema, and thrombocytosis. A condition that satisfies the 3 major criteria and 1 or more minor criteria is definitively diagnosed as POEMS syndrome ${ }^{2}$. About half of the patients present with polyneuropathy, and the remainder present with edema or skin manifestations (increased skin pigmentation, bristly hair, and/or angiomas); men often present with gynecomastia. During screening or assessment for various other conditions, pleural effusion/ascites, monoclonal proteins, and high levels of Cre are often detected ${ }^{5)}$. Multiple symptoms arise as the condition progresses. During the initial examination, physicians must take a systematic approach to the differential diagnosis, keeping POEMS syndrome in mind so that the condition can be diagnosed early.

The patient's hyperkalemia was noted on the 
day of his initial admission. On hospital day 3, however, fluid replacement primarily with extracellular fluid solution alleviated the electrolyte abnormalities, so adrenal insufficiency could not have been predicted on admission. Despite the fluid and electrolyte replacement therapy, the patient's $\mathrm{Na} / \mathrm{K}$ ratio gradually decreased, and by hospital day 12 , prompt correction of the electrolyte levels was necessary (Fig. 5). The patient's blood pressure on initial admission (and while he was taking losartan) was $130 / 77 \mathrm{mmHg}$, but it decreased to $95 / 57 \mathrm{mmHg}$ by the time he was treated in our department. Given the decreased blood pressure and elevated BUN and Cre levels, adrenal insufficiency was presumed to have developed. Ascites is noted in 7-54\% of cases of POEMS syndrome ${ }^{6}$. The patient we describe was admitted for further examination of abdominal distention resulting from ascites, and it is likely that the subsequent fasting, fluid replacement therapy, and paracentesis caused physiological and psychological stress. The stress may have been the cause of acute exacerbation of adrenal insufficiency as a manifestation of the POEMS syndrome.

Five cases of adrenal insufficiency in association with POEMS syndrome have been reported (Table 2$)^{7-11)}$. In 3 of these cases $^{7-9)}$, adrenal insufficiency was originally diagnosed and treated, but other symptoms developed during treatment, leading to a diagnosis of POEMS syndrome 5 months to 2 years after the original diagnoses. In 2 of the 5 cases $^{10) 11}$, the adrenal insufficiency was diagnosed on the basis of endocrine tests, but with the exception of the case we report, there are no reported cases in which adrenal insufficiency developed and led to a diagnosis of PO-

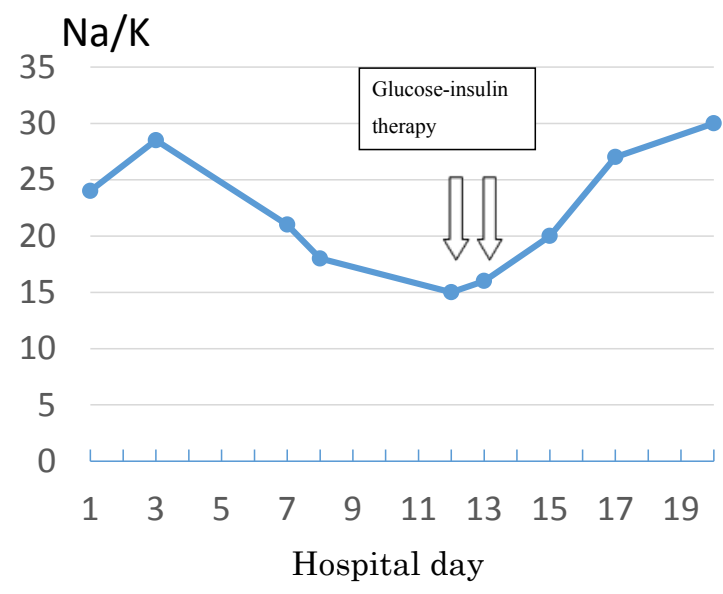

Figure 5. Patient's sodium/potassium ratio during the course of hospitalization.
EMS syndrome. Gandhi et al. examined results of endocrine tests performed in 64 patients with POEMS syndrome and found endocrinopathy in $54(84 \%)$ of these patients ${ }^{1}$. The most common endocrine abnormality was hypogonadism, followed by hypothyroidism and impaired glucose tolerance. Nine patients underwent a rapid ACTH stimulation test, and 6 of these 9 were diagnosed with adrenal insufficiency. According to Gandhi et al., endocrine abnormalities are not evaluated in many cases of POEMS syndrome, and such cases are instead diagnosed on the basis of other criteria. In fact, endocrine abnormalities have, in the past, seldom been assessed in patients with POEMS syndrome. The onset of endocrine abnormalities in POEMS syndrome presumably involves VEGF, but autoantibodies against endocrine glands have not been detected ${ }^{12)}$, and autopsies have revealed no structural endocrine gland abnormalities. Thus, functional abnormalities presumably cause the endocrine abnormalities ${ }^{13)}$. Adrenal insufficiency is a condition that causes a variety of symptoms. When polyneuropathy, ascites, and swollen lymph nodes are noted along with adrenal insufficiency, POEMS syndrome must be included in the differential diagnosis, even though adrenal insufficiency linked to POEMS syndrome is rare. The case we describe is highly instructive because the POEMS syndrome was not diagnosed on the basis of the clinical interview, and it was not considered during the early examinations despite the presence of hyperpigmentation and foot numbness. The adrenal insufficiency was key to the diagnosis.

\section{Acknowledgement}

The authors wish to thank Professor Satoshi Kuwabara of the Department of Neurology, Chiba University, who treated the patient described herein.

Authors' COI disclosure: The authors have no conflict of interest to disclose with regard to this report.

\section{References}

1) Gunjan Y, Gandhi R, Angela D, Ananda B, Victor M. Montori, Michael D. Brennan. Endocrinopathy in POEMS syndrome: The Mayo Clinic experience. Mayo Clin Proc 2007; 82: 836-842.

2) Kuwabara S, Dispenzieri A, Arimura K, Misawa S. Treatment for POEMS (polyneuropathy, organomegaly, endocrinopathy, M-protein, and skin changes) syndrome. Cochrane Database Syst Rev 2008; 8: CD006828. doi: 10.1002/14651858. 
Table 2. Reports of Adrenal Insufficiency in Patients with POEMS Syndrome.

\begin{tabular}{|c|c|c|c|c|c|}
\hline Patient & $\begin{array}{c}\text { Chief } \\
\text { complaint(s) }\end{array}$ & $\begin{array}{c}\text { Symptoms of POEMS } \\
\text { syndrome }\end{array}$ & $\begin{array}{c}\text { Diagnosis of } \\
\text { adrenal } \\
\text { insufficiency }\end{array}$ & $\begin{array}{l}\text { Treatment and } \\
\text { outcome }\end{array}$ & Reference \\
\hline 44-year-old man & $\begin{array}{l}\text { Visual } \\
\text { impairment }\end{array}$ & $\begin{array}{l}\text { Optic nerve edema, } \\
\text { polyneuropathy, } \\
\text { osteosclerotic lesions, } \\
\text { polycythemia }\end{array}$ & $\begin{array}{l}\text { Two years prior, } \\
\text { hypogonadism } \\
\text { and adrenal } \\
\text { insufficiency were } \\
\text { noted. The patient } \\
\text { was taking } \\
\text { hydrocortisone. } \\
\text { Impaired vision } \\
\text { led to a diagnosis } \\
\text { of POEMS } \\
\text { syndrome. }\end{array}$ & $\begin{array}{l}\text { The myeloma was } \\
\text { treated with } \\
\text { radiation therapy } \\
\text { and } \\
\text { dexamethasone. }\end{array}$ & $\begin{array}{l}\text { Surv Opthalmol } \\
59: 128-131, \\
2014 .\end{array}$ \\
\hline 32-year-old man & Malaise & $\begin{array}{l}\text { Malaise, thinning } \\
\text { body hair, edema, leg } \\
\text { pain, increased } \\
\text { pigmentation of the } \\
\text { areolae, erectile } \\
\text { dysfunction }\end{array}$ & $\begin{array}{l}\text { One year prior, } \\
\text { malaise and } \\
\text { bristly hair were } \\
\text { noted. Six months } \\
\text { prior, treatment } \\
\text { with } \\
\text { hydrocortisone } \\
\text { yielded no } \\
\text { improvement. } \\
\text { Upon admission, } \\
\text { POEMS } \\
\text { syndrome was } \\
\text { diagnosed. }\end{array}$ & $\begin{array}{l}\text { Symptoms were } \\
\text { alleviated with } \\
\text { pulse } \\
\text { corticosteroids, } \\
\text { treatment with } \\
\text { melphalan and } \\
\text { prednisone, and } \\
\text { autologous stem } \\
\text { cell transplantation. }\end{array}$ & $\begin{array}{l}\text { J Japanese Soc } \\
\text { Internal Med } \\
\text { 100:3038-3040, } \\
2011 .\end{array}$ \\
\hline 42-year-old woman & $\begin{array}{l}\text { Fatigue, } \\
\text { constipation, } \\
\text { amenorrhea }\end{array}$ & $\begin{array}{l}\text { Increased skin } \\
\text { pigmentation, swollen } \\
\text { axillary lymph nodes, } \\
\text { hepatosplenomegaly, } \\
\text { hypothyroidism, } \\
\text { polyneuropathy }\end{array}$ & $\begin{array}{l}\text { Five months prior, } \\
\text { malaise, } \\
\text { constipation, and } \\
\text { amenorrhea were } \\
\text { noted. ACTH } \\
\text { stimulation testing } \\
\text { led to a diagnosis } \\
\text { of adrenal } \\
\text { insufficiency, and } \\
\text { hydrocortisone } \\
\text { was administered. } \\
\text { Further } \\
\text { examination of } \\
\text { other symptoms } \\
\text { led to a diagnosis } \\
\text { of POEMS } \\
\text { syndrome. }\end{array}$ & $\begin{array}{l}\text { Autologous stem } \\
\text { cell transplantation } \\
\text { was performed. In } \\
4 \text { years, adrenal } \\
\text { function improved. }\end{array}$ & $\begin{array}{l}\text { Medscape Med } \\
11: 21,2009 .\end{array}$ \\
\hline 36-year-old man & $\begin{array}{l}\text { Lower back } \\
\text { pain }\end{array}$ & $\begin{array}{l}\text { Polyneuropathy, } \\
\text { vertebrae with a } \\
\text { mixture of } \\
\text { osteosclerosis and } \\
\text { osteolysis, increased } \\
\text { skin pigmentation, } \\
\text { gynecomastia, } \\
\text { hepatosplenomegaly, } \\
\text { shrinking of the testes, } \\
\text { swollen lymph nodes, } \\
\text { ascites }\end{array}$ & $\begin{array}{l}\text { ACTH stimulation } \\
\text { testing led to a } \\
\text { diagnosis of } \\
\text { adrenal } \\
\text { insufficiency. }\end{array}$ & $\begin{array}{l}\text { Symptoms were } \\
\text { alleviated with } \\
\text { radiation therapy } \\
\text { and treatment with } \\
\text { melphalan and } \\
\text { prednisone. }\end{array}$ & $\begin{array}{l}\text { J Med Assoc } \\
\text { Thai 76:585- } \\
590,1993 \text {. }\end{array}$ \\
\hline 63-year-old man & $\begin{array}{l}\text { Osteosclerotic } \\
\text { myeloma and } \\
\text { other symptoms }\end{array}$ & $\begin{array}{l}\text { Polyneuropathy, } \\
\text { hepatosplenomegaly, } \\
\text { optic nerve edema, } \\
\text { ascites, increased skin } \\
\text { pigmentation, } \\
\text { papilledema }\end{array}$ & $\begin{array}{l}\text { Cortisol levels } \\
\text { were assessed, } \\
\text { and a low } \\
\text { morning cortisol } \\
\text { level }(8.2 \mathrm{~g} / \mathrm{mL}) \text {, } \\
\text { led to a diagnosis } \\
\text { of adrenal } \\
\text { insufficiency. }\end{array}$ & $\begin{array}{l}\text { Hormone } \\
\text { replacement } \\
\text { therapy was } \\
\text { started. Treatment } \\
\text { with melphalan and } \\
\text { prednisone was } \\
\text { ineffective. } \\
\text { plasmapheresis was } \\
\text { performed, but the } \\
\text { patient died } \\
\text { subsequently. }\end{array}$ & $\begin{array}{l}\text { J Clin Apher } \\
2: 253-257 \\
1985 .\end{array}$ \\
\hline $\begin{array}{l}\text { 57-year-old man } \\
\text { (our patient) }\end{array}$ & $\begin{array}{l}\text { Bloating, } \\
\text { numbness in the } \\
\text { lower limbs }\end{array}$ & $\begin{array}{l}\text { Polyneuropathy, } \\
\text { hepatosplenomegaly, } \\
\text { ascites, increased skin } \\
\text { pigmentation, } \\
\text { hypertrichosis, } \\
\text { swollen lymph nodes }\end{array}$ & $\begin{array}{l}\text { Electrolyte } \\
\text { abnormalities } \\
\text { were noted on } \\
\text { admission. } \\
\text { Adrenal } \\
\text { insufficiency was } \\
\text { suspected, so an } \\
\text { ACTH stimulation } \\
\text { test was } \\
\text { performed. } \\
\text { Results led to a } \\
\text { diagnosis of } \\
\text { adrenal } \\
\text { insufficiency. }\end{array}$ & $\begin{array}{l}\text { Symptoms were } \\
\text { alleviated with } \\
\text { thalidomide and } \\
\text { dexamethasone. }\end{array}$ & $\begin{array}{l}\text { Case described } \\
\text { herein }\end{array}$ \\
\hline
\end{tabular}

ACTH: adrenocorticotropic hormone 
CD006828.pub2.

3) Osame M, Arimura K, Uehara A. 2004 National epidemiological survey of Crow-Fukase syndrome, Research Committee on Autoimmune Neurological Disorders of the Ministry of Health. Labour and Welfare 2004 Report, Tokyo, 2004: 141-144.

4) Kuwabara S. The pathology of and new treatments for Crow-Fukase syndrome. Nihon Naika Gakkai Zasshi 2011; 100: 2275-2281.

5) Nakanishi T, Sobue I, Toyokura Y, Nishitani H, Kuroiwa Y, Satoyoshi E, Tsubaki T, Igata A, Ozaki Y. The Crow-Fukase syndrome. a study of 102 cases in Japan. Neurology 1984; 34: 712-720.

6) Dispenzieri A. POEMS syndrome: 2014 update on diagnosis, risk stratification, and management. Am J Hematol 2014; 89: 214-223.

7) Lally DR, Moster ML, Foroozan R. Muscle cramping over the diagnosis. Surv Opthalmol 2014; 59: 128-131.

8) Itoh Y, Hayakawa N, Okamura T, Tomoko O, Takayanagi T, Suzuki A, Oda N, Ueda A, Inaguma Y, Emi N, Itoh M. A case of POEMS syndrome with endocrinopathy. Nihon Naika Gak- kai Zasshi 2011; 100: 3038-3040.

9) Ashawesh K, Fiad TM. Spontaneous recovery of adrenal insufficiency in POEMS syndrome. Medscape J Med 2009; 11: 21.

10) Intragumtornchai $T$, Phanthumchinda $K$, Lerdlum S, Supmpathanikul P, Sakulramrung R. POEMS syndrome: a case with proliferative vasculopathy and a review of cases Thailand. J Med Assoc Thai 1993; 76: 585-590.

11) Silberstein LE, Duggan D, Berkman EM. Therapeutic trial of plasma exchange in osteosclerotic myeloma associated with the POEMS syndrome. J Clin Apher 1985; 2: 253-257.

12) Bardwick PA, Zvaifler NJ, Gill GN, Newman D, Greenway GD, Resnick DL. Plasma cell dyscrasia with polyneuropathy, organomegaly, endocrinopathy, $\mathrm{M}$ protein, and skin changes: the POEMS syndrome. Report on two cases and a review of the literature. Medicine (Baltimore) 1980; 59: 311-322.

13) Gherardi R, Baudrimont M, Kujas M, Malapert D, Lange F, Gray F, Poirier J. Pathological findings in three non-Japanese patients with the POEMS syndrome. Virchows Arch A Pathol Anat Histopathol 1998; 413: 357-365. 